\title{
CHARLES DARWIN AND IDEOLOGY RETHINKING THE DARWINIAN REVOLUTION
}

\section{JANET BROWNE}

This short paper critiques the idea of any coherent Darwinian ideology. Charles Darwin himself did not adopt any obvious ideology, except perhaps that of anti-slavery. However, his published work, and that of other evolutionists, led to the emergence of social Darwinism. Herbert Spencer's role in fostering social Darwinism, and the rise of eugenics, are briefly described. The connection, if any, between the historical figure of Darwin and the social movement that bears his name is discussed. While Darwin's On the origin of species or The descent of man can hardly account for all the racial stereotyping, nationalism, or political bigotry seen in the half century after his death, there can be no denying the impact of his work in providing an authoritative biological backing for eugenics, colonial belligerence, and western notions of racial superiority.

Keywords: social Darwinism, Herbert Spencer, evolution, competition.

\section{WHAT KIND OF IMPACT?}

When probing the relations between science and ideology, the impact of Charles Darwin is unquestionably among the most interesting topics for analysis. As a historical figure Darwin was remarkable for the manner in which his scientific ideas codified the predominant themes of his era and also precipitated debates that ultimately led to sweeping transformations in religious, cultural, and scientific thought. These major shifts in the larger political and cultural context are widely known as the «Darwinian

"FROM HIS BIRTH, CHARLES DARWIN ABSORBED THE PREVAILING IDEOLOGY OF INDUSTRIAL AND COLONIAL PROGRESS"
BORN INTO AN INDUSTRIAL, COLONIAL AGE

Darwin's life (1809-1882) spanned most of the nineteenth century and his science reflected the industrial and political transformations for which Britain was then famous. From his birth, he absorbed the prevailing ideology of industrial and colonial progress. He was born in the British industrial Midlands, in the town of Shrewsbury, to a prosperous medical family, whose wealth rested mainly on successful manufacturing entrepreneurship. One of his grandfathers was Josiah Wedgwood, the china manufacturer, who was a leading figure in the British industrial revolution and the anti-slavery movement of the day. Wedgwood transformed the consumer market with his factory-produced chinaware but 
also participated in developing new manufacturing operations through applying ideas such as the division of labor and opened up the British transport infrastructure by investing in canals and roads. Much of the financial and social capital on which the family's prosperity rested derived from Josiah Wedgwood's commercial success.

Darwin's other grandfather was the prominent physician, liberal thinker, and literary figure, Dr. Erasmus Darwin. Erasmus Darwin was a member of the small circle of improvers, factory owners, medical men, and politically progressive intellectuals who called themselves the Lunar Society (Uglow, 2002). Erasmus Darwin had three sons, one of whom was also a physician with an inquiring mind - he was Charles Darwin's father. The Darwin-Wedgwood circle was passionate in its support for abolitionism and the young Darwin adopted this frame of mind (Desmond \& Moore, 2009). The family's intellectual pursuits, along with their professional social standing, polite religious skepticism, high levels of education, commercial acumen, and liberal political views ensured that Charles Darwin always had a place in intellectual British society as well as the prospect of a comfortable financial inheritance, both of which were material factors in his later achievements.

It is not necessary to repeat the main events of Darwin's life (Browne, 1995, 2002; Desmond \& Moore, 1990). But it is useful to recall that his education at two of the most elite universities of the time and the opportunity to travel on the British Admiralty voyage in HMS Beagle, not only reflected the advantages of his family's social position and his personal talent for natural history, but also the primacy of the prevailing scientific and colonial ideology. If Darwin consciously adopted any political ideology at this time, it was one of colonial expansionism.

\section{GREAT CURRENTS OF CHANGE}

More generally, during Darwin's lifetime, great currents of change were making their presence felt. Politically, Europe was shaken by the Napoleonic wars, then by civil unrest. In the 1830s the British nation came as close to political revolution as it ever did - conflict between landlords and manufacturers, workers against masters, province versus metropolis, the hungry and mutinous threatening the commercially-minded, individualistic middle classes. Prime Minister Benjamin Disraeli's imagery of two nations, rich and poor, was not over-fanciful. At the end of the century, the country was again at war, this time in South Africa. By then imperial expansion and the second industrial revolution - marked by the coming of the railways, significant urbanisation, the rise of the middle classes, increasing literacy and prosperity, consumerism, and widespread dissemination of printed texts - was well under way. The prevailing utilitarianism, although mostly concerned with legal and social reform, supported this emerging frame of mind, in which the right action was the action that produced the most good, or that all rights were underwritten by utility. From the 1850s a new and varied economy was soaking up excess capital, leading to a diversification in the labor force. And in religious terms, although the Protestant (Anglican) faith provided the framework in which most British people operated, the grip of the Church was loosening. Dissenting and non-conformist Protestant groups claimed the right to worship in their own manner, to educate the young, to be represented in parliament, to take public position and have their views heard.

In science, matters were similarly expanding, diversifying, and refocusing. One by one, Victorian thinkers aimed to investigate the world around them without recourse to the bible's word or the Church's doctrinal authority (Lightman, 1987). Religious doubts, secular inclinations, and dissatisfaction with conventional religious doctrines, especially the prevailing natural theology, were launched among intellectuals long before Darwin came on the scene. Importantly, too, there was rising engagement with science among many different sectors of the British public (Lightman \& Fyfe, 2007).

By the time Darwin published On the origin of species, the nation was full of industrial diversification, commercial and professional specialization, religious tension, intense colonial activity, and among the middle-classes much talk of «improvement» and «progress». The selfcongratulatory sense of the era was captured by the Great Exhibition of the Works of Industry of all 


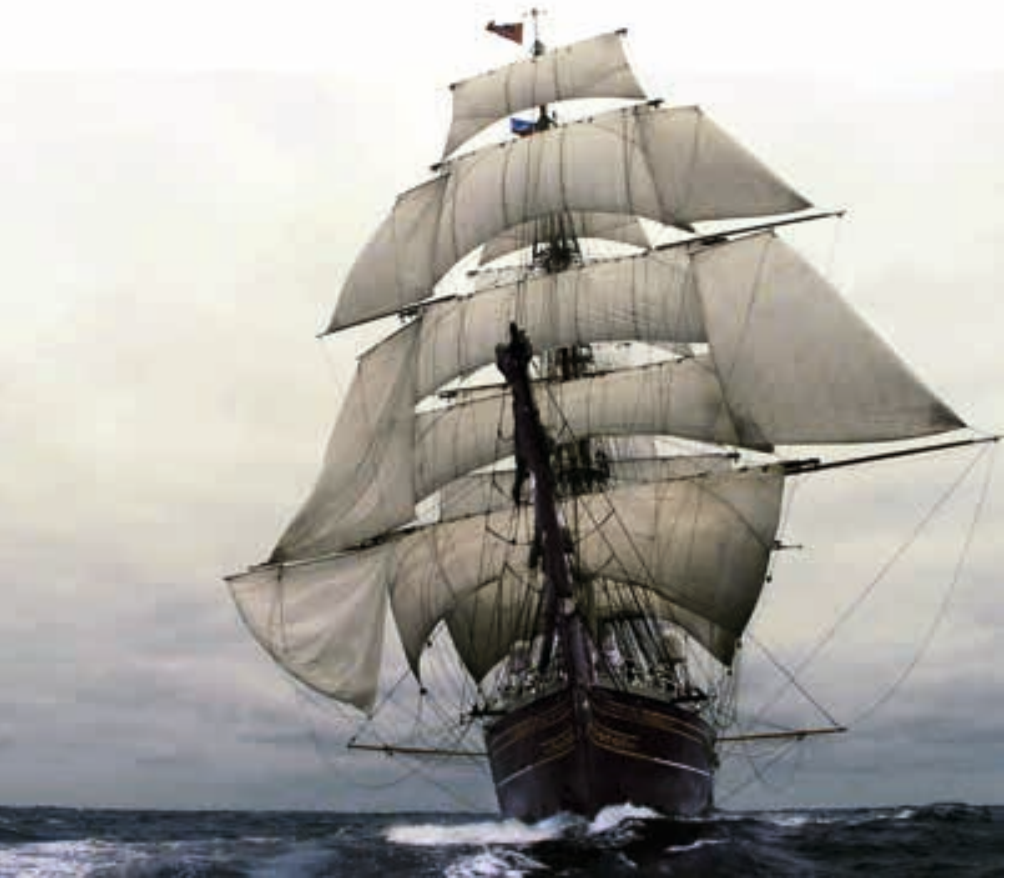

Darwin's education at two of the most elite universities of the time and the opportunity to travel on the British Admiralty voyage in HMS Beagle, not only reflected the advantages of his family's social position and his personal talent for natural history, but also the primacy of the prevailing expansionist scientific and colonial ideology.

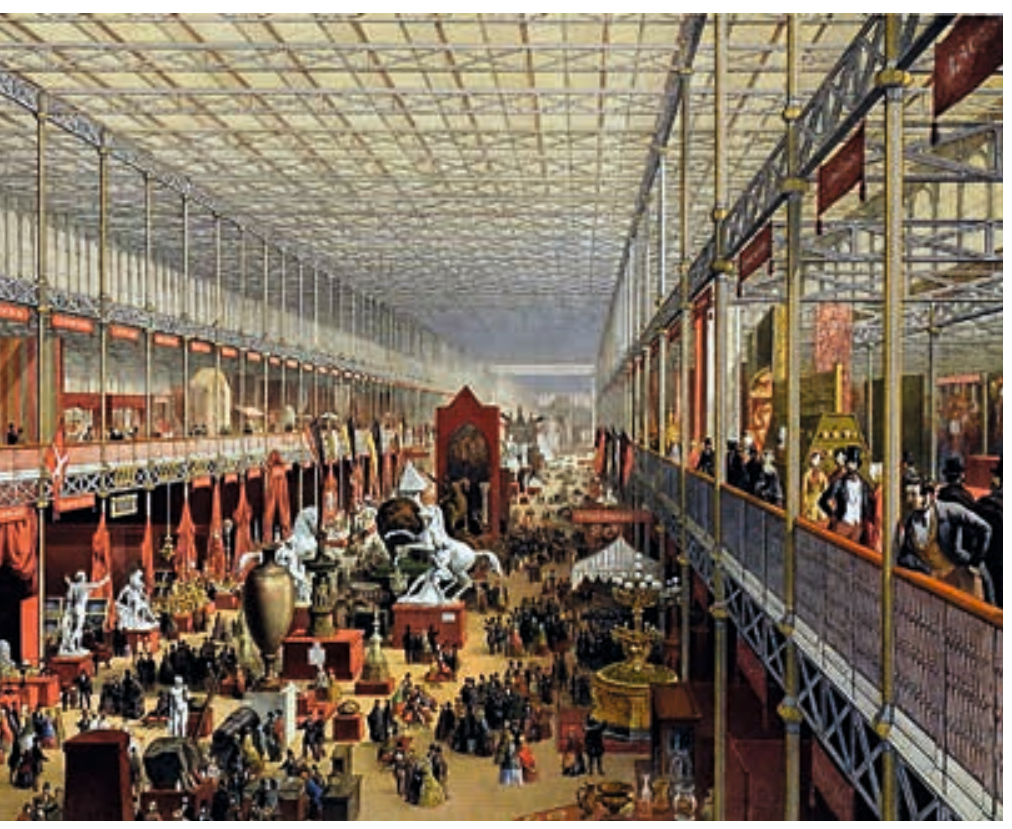

By the time Darwin published On the origin of species, the nation was full of industrial diversification, commercial and professional specialization, religious tension, intense colonial activity, and among the middle-classes much talk of «improvement» and "progress". In the image, a coloured lithograph by J. McNeven (1851), The foreign department, viewed towards the transept, shows an interior view of the Crystal Palace in London during the Great Exhibition of 1851.
Nations held in 1851 in central London, in the giant glass exhibition hall often called the Crystal Palace. Perhaps because of this apparent national success, there was also widespread middle-class unease about any social, political, or intellectual activities that threatened the status quo. Among these threats were evolutionary notions. To adopt transmutation, such as in the anonymous book authored by Robert Chambers in 1844 (Secord, 2003), or to promote points of view that advocated self-determination, such as the doctrine of phrenology (Cooter, 1984), was at that time to brand oneself as a dangerous political radical who might favor atheism, materialism, and political upheaval; someone who could contribute to the destabilization of the state (Desmond, 1989). The Victorian frame of mind evidently combined many elements, including religious uncertainty, the industrial ethos, a strong sense of national progress, political conservatism, colonial expansion, and a subterranean world of popular dissent.

\section{NATURAL SELECTION}

All these elements found a place in Charles Darwin's theories - and in the theories of his contemporary Alfred Russel Wallace, who also formulated a theory of evolution by natural selection. The essence of Darwin's and Wallace's proposals was that living beings should not be regarded as the carefully constructed «perfect» creations of a divine authority but as the products of entirely natural processes. They proposed that species emerge naturally from other species through competition among individuals and the survival («selection») of the best-adapted forms. In their scheme, organisms diversified in a longcontinued, gradual process.

Famously, both Darwin and Wallace derived the concept of natural selection from the work of the British political economist, Thomas Robert Malthus, An essay on the principle of population (1798). Darwin's direct and vivid engagement with Malthus has served as an excellent case study for scholars in the intermeshing of science and society (Young, 1985). Malthus's intention was to explain how human populations remain in balance with the means to feed them - his essay was an important contribution to the political economy of Britain in the 1790s. By the 1830s, when Darwin read it, Malthusian doctrines were part of government policy. The argument was starkly simple. The natural tendency of mankind, Malthus said, was always to increase in numbers. Food production would never keep up. Yet there was an approximate balance, Malthus claimed, because 
the number of individuals is kept in check by famine, disease, or death by warfare. Malthus believed that such checks usually fell on the weakest members of society - the poorest and sickest. He also believed that it was God's will that this should happen so. One consequence, Malthus warned, was that giving charity (such as welfare payments) to the poor would encourage more reproduction and even greater pressure on food supplies. These opinions were made real by the passing of the Poor Law Amendment Bill in 1834 that introduced the workhouse to Britain, in which the indigent poor were obliged by law to exchange their labor for food. This was the world described by the novelist Charles Dickens in Oliver Twist.

Darwin applied Malthus's ideas to the animal and plant kingdoms. Very many individuals are born, Darwin noted. This must result in a struggle for existence - individuals compete with each other to survive. In this competition, the weakest organisms would tend to die first. Only the survivors would have offspring. Darwin added to Malthus the notion that if the survivors survived by being very slightly better adapted, these adaptations would be passed on to the next generation. Survivors would tend to become better suited to their conditions of existence. The process would also stimulate the diversification of organisms to capitalize on different niches in the natural economy, just like the manufactories of Darwin's era. Independently, but contemporaneously, Wallace made much the same suggestion (Costa, 2014).

\section{SOCIAL DARWINISM}

The story of the publication and responses to Darwin and Wallace's ideas has been well told elsewhere (Browne, 2002; Desmond \& Moore, 1990; Lightman, 2007). More relevant here, is that over time, these biological ideas became the foundation for a new ideology called social Darwinism. In a literal sense, the phrase social Darwinism means merely the application of Darwin's biological ideas to human society: a commitment to Darwin's and Wallace's ideas about competition and survival of the fittest acting similarly in human affairs as in biology.

Commentators, however, frequently describe the leading facets of social Darwinism much more widely, including laissez-faire economic practices, competitive commercial practices, the adoption of ideas of racial hierarchy, and strong bias in class and gender issues, as well as support for eugenics, imperialism, nationalism, and colonial appropriation (Bannister, 1989; Hawkins, 1997). As such, it is a
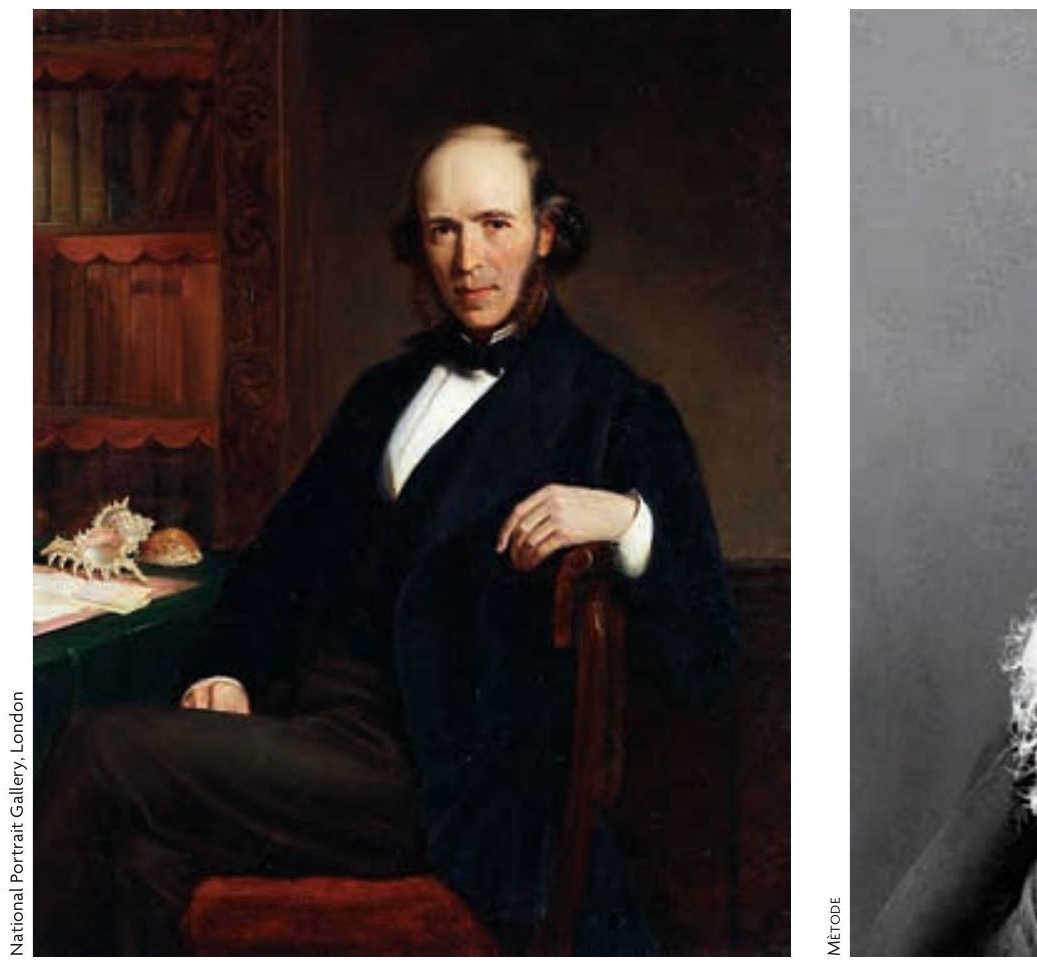

Herbert Spencer supported laissez-faire capitalism on the basis of his belief that struggle for survival would spur self-improvement that could be inherited. He was the originator of the expression "survival of the fittest" that was adopted by both Darwin and Wallace. In the picture, Herbert Spencer's portrait by John Bagnold Burgess (1872).

social ideology that has had worldwide impact far beyond biology, especially in Europe and the United States of America from around 1870-1950. It is also generally associated with the rise of fascism in the 1920s and 1930s, with Adolf Hitler's crusade for racial purity, and with aggressive individualism in capitalist political systems and the business community (Weikart, 2006). It is a term that therefore comes freighted with a great deal of negative feeling, epitomised by Richard Hofstadter's Social Darwinism in American thought, 1860-1915 (1944) that presented a critique of late nineteenth-century American capitalism and its ruthless «dog-eat-dog» economic competition. It is probably more accurate to refer to social evolutionism rather than social Darwinism, but this verbal adjustment has never caught on. The term social Darwinism gained widespread currency after Hofstadter used it, although it seems to have appeared before then in the literature. The majority of those who have been categorized as social Darwinists apparently did not identify themselves by such a label. It is almost always used pejoratively. 


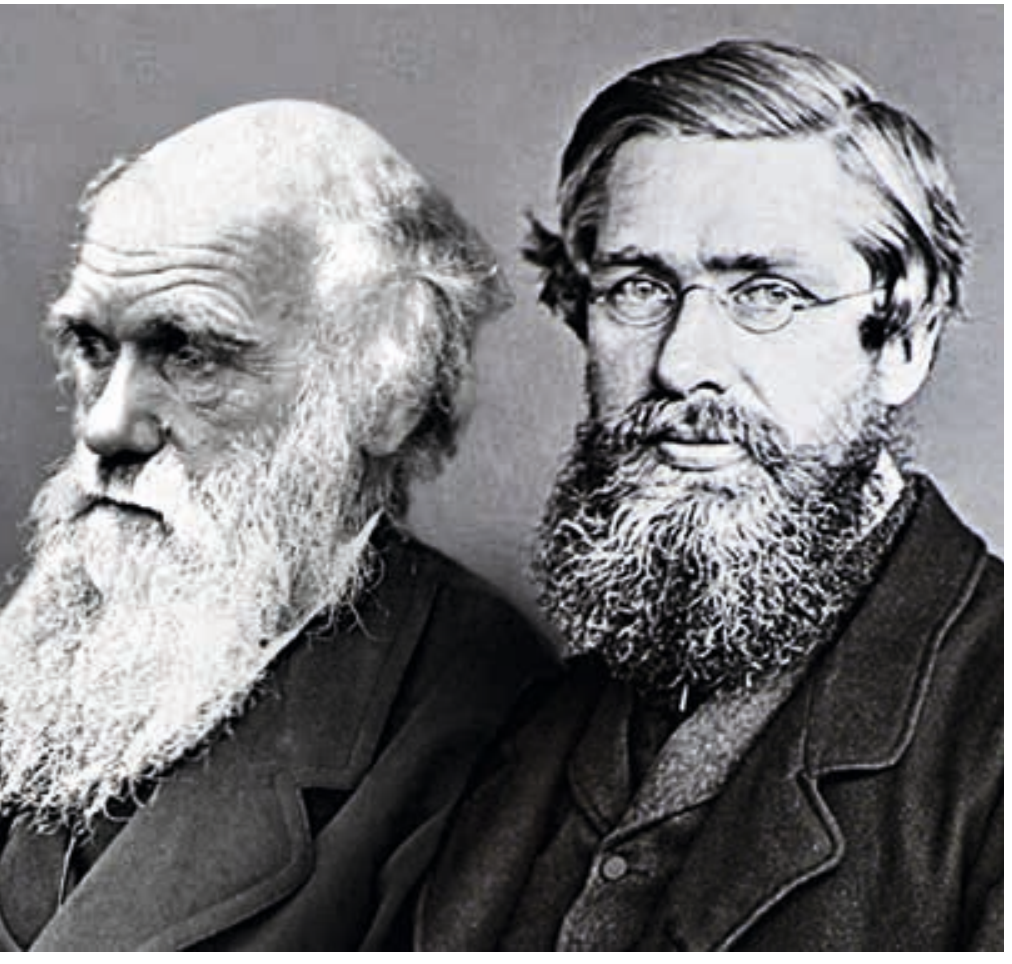

The essence of Charles Darwin's (on the left) and Alfred R. Wallace's (on the right) proposals was that living beings should not be regarded as the carefully constructed "perfect" creations of a divine authority but as the products of entirely natural processes. -that they were governed by the same immutable laws and controlled by the same forces of nature.

Like the French philosopher and sociologist Auguste Comte, several of whose ideas he adopted, Spencer was a positivist and a fierce critic of established religion. He applied his own form of evolutionary theory to philosophy, psychology, biology, and the study of society, and believed that the natural growth of society required liberty, which in turn justified absolute individualism. So Spencer supported laissez-faire capitalism on the basis of his belief that struggle for survival would spur selfimprovement that could be inherited. Spencer, not Darwin, coined the phrase «survival of the fittest», and Darwin, in later editions of $O n$ the origin of species employed Spencer's phrase. Following his doctrine of the survival of the fittest, Spencer therefore opposed any form of charity that might be thought to maintain the unfit members of society. This expression «survival of the fittest» became the leitmotif of what people commonly understood Darwinism and social Darwinism to be about.

Certainly, a great deal of social Darwinism can be attributed to the popularity of Spencer's writings (Spencer, 1891). His successful overseas lecture tours brought the key ideas of competition and survival to the United States and elsewhere. By the end of the century, these ideas were being put into action by the business entrepreneurs who masterminded the development of North American industry, such as John D. Rockefeller, or the railway tycoon James J. Hill, who used «survival of the fittest» as a catch phrase. In their view, the strongest and most efficient company would dominate the market and stimulate economic progress on the wider scale. Andrew Carnegie, the émigré Scots philanthropist, and steel magnate, revered Herbert Spencer (Werth, 2011). Such commitments were generally, if not exclusively, biased towards the political right. None of these thinkers believed in the emerging socialist movement or in state support for the poor. It was assumed that any circumvention of Darwinism's «natural laws» would encourage idleness and permit «unfit» businesses to survive, thereby undercutting economic and national progress. Only Alfred Russel Wallace seems to have stood firm against this tide of thought, a tide of thought that used his and Darwin's biological ideas to support the rising capitalist economy. 


\section{EUGENICS}

Enthusiasm for social Darwinism merged readily into growing ideologies of imperialism, racialism, and eugenics. The «survival of the fittest» here supported contemporary notions of inbuilt racial difference and appeared to vindicate continuing fights for territory and political power on the international stage (Paul, 2009). The evident success of white Europeans in conquering and settling in foreign lands seemed to make natural the subjugation of indigenous peoples or even the near-extermination of populations such as Tasmanian Aboriginals. Conquest was deemed a necessary part of progress. Karl Pearson, a committed Darwinist and London statistician, expressed a typical view. No one should regret, he said in 1892, that, «a capable and stalwart race of white men should replace a dark-skinned tribe which can neither utilise its land for the full benefit of mankind, nor contribute its quota to the common stock of human knowledge» (Pearson, 1892, p. 369).

Social commentators appeared to agree. Eugenics was given its name and leading principles by Francis Galton in the 1880s, drawing on social and racial assumptions already well established but acquiring greater force when attached to evolutionary theory (Kevles, 1985). Galton (who was Darwin's cousin) feared that civilized societies tended generally to prevent natural selection working, in the sense that many of the «unfit» were preserved by medical intervention, charity, or religious principles, whereas in a state of nature such people would die without reproducing. The worst elements of society were the most fecund, he said. He campaigned tirelessly, but unsuccessfully, for the reduction of the birth rate among people he categorized as indigent, unfit, or profligate, and promoted the idea of more births among the «worthy» middle classes. Eugenics became one of the most pervasive scientific movements of the early twentieth century, spreading widely through Europe and the Americas. It focused middle-class concerns about possible racial and national decline and projected them onto the «unfit» in society. In this way social Darwinism again exhibits the interlacing of science and prevailing ideologies. Many eugenists were advocates for technological and scientific advance. Many were committed socialists and supporters of women's suffrage, and yet they also promoted nationalism, chauvinism, selection, and prejudice. In the hands of the fascist movements of the 1930s these ideas became deeply political and ultimately expressed through Hitler's ideas of lebensraum (living space) and racial purity.

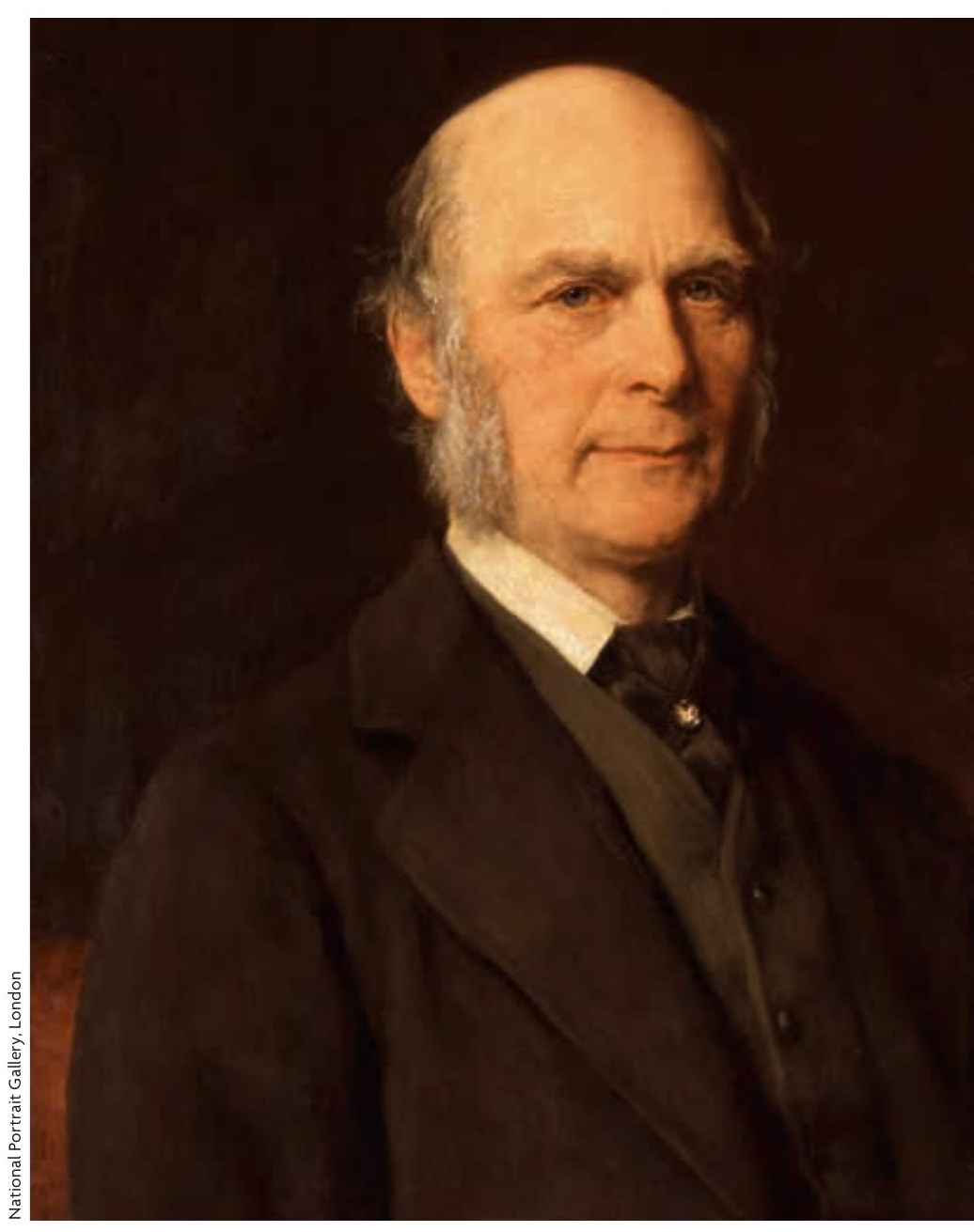

Eugenics was given its name and leading principles by Francis Galton in the 1880s, drawing on social and racial assumptions already well established but acquiring greater force when attached to evolutionary theory. Above, Francis Galton's portrait by Gustav Graef (1882). On the right, a page from one of Galton's most important books, Inquiries into human faculty and its development, published in 1883.

\section{SCIENCE AND IDEOLOGY}

Karl Marx, as profoundly insightful and influential as Charles Darwin, died a stateless person and was buried in 1883 without ceremony in a London cemetery. Charles Darwin, by contrast, on his death in 1882, was widely celebrated as a great national hero in science and buried in Westminster Abbey, in London, the most prominent commemorative site in Britain. His name subsequently became fixed in the global imagination as designating a major social and political movement that intermeshed very closely with existing British Victorian ideologies, and also as the instigator of a fundamental transition in science that spoke to a new emphasis on rationality 


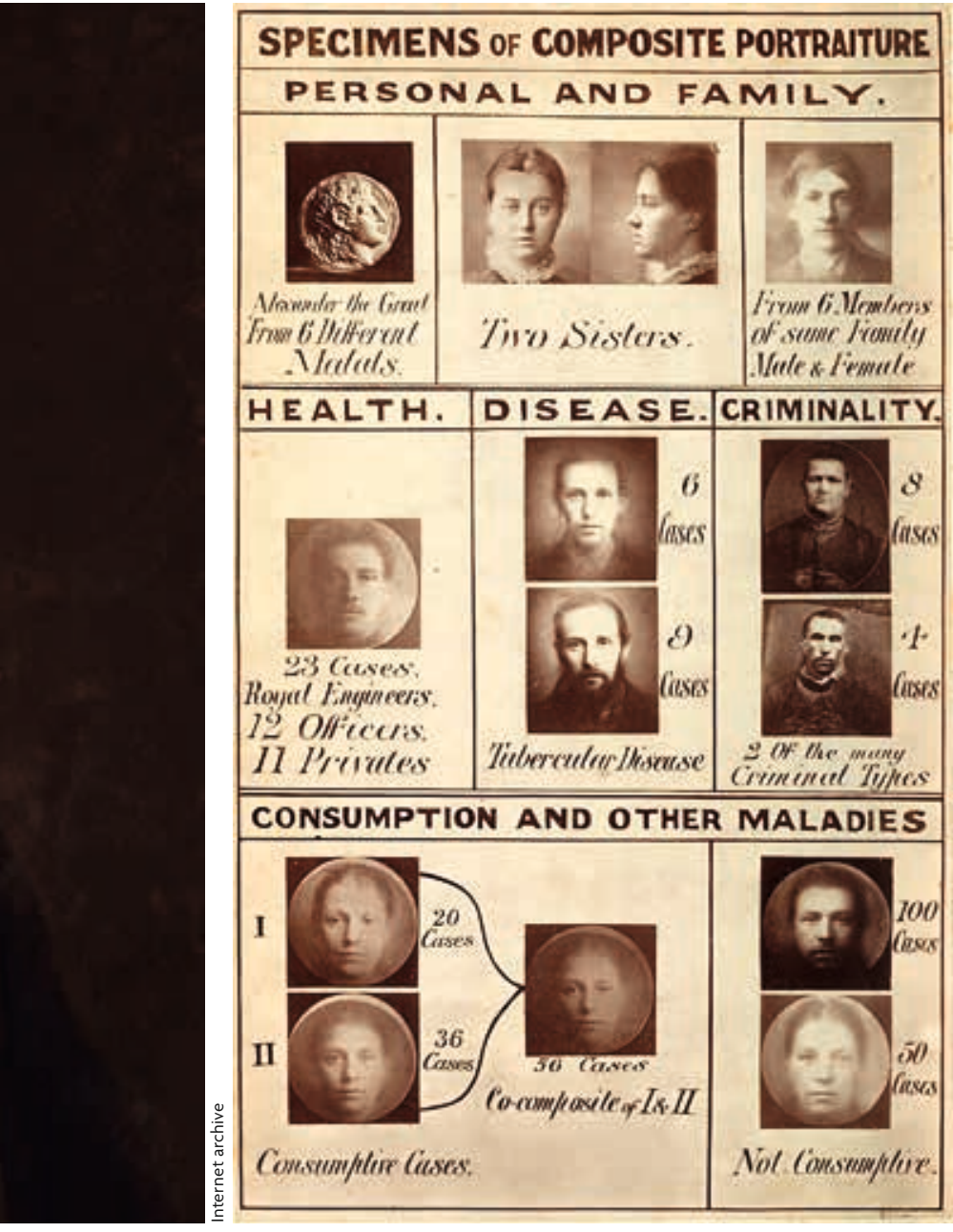

and naturalism, one that apparently removed all dependence on biblical notions. This is what we understand as the modern frame of mind.

While Darwin's On the origin of species or The descent of man can hardly account for all the racial stereotyping, nationalist fervor, and bigotry to be found in the decades after his death, there can be no denying the impact of his writings in providing an authoritative biological backing for a new ideology that combined science, eugenics, warfare, colonialism, notions of racial difference, and the superiority of western civilization. These facts indicate very clearly that science and scientific ideas were at that time completely embedded in political-cultural movements and that there was much reciprocity at work. Darwin drew his ideas from Malthusian political ideology and turned them into biology. Then, after Darwin published his two greatest works, On the origin of species and The descent of man, these biological ideas moved back into Victorian political economy in the form of social Darwinism. Yet this latter movement included much more than just Charles Darwin's concepts - it included all the transformative themes of the era, as well as the important views of other evolutionists such as Herbert Spencer.

\section{REFERENCES}

Bannister, R. (1989). Social Darwinism: Science and myth in AngloAmerican social thought. Philadelphia: Temple University Press.

Bowler, P. J. (2013). Darwin deleted: Imagining a world without Darwin. Chicago: University of Chicago Press.

Browne, E. J. (1995). Charles Darwin: A biography. Vol. 1. Voyaging. New York: Knopf.

Browne, E. J. (2002). Charles Darwin: A biography. Vol.2. The power of place. New York: Knopf.

Cooter, R. (1984). The cultural meaning of popular science: Phrenology and the organization of consent in nineteenth-century Britain. Cambridge: Cambridge University Press.

Costa, J. T. (2014). Wallace, Darwin, and the origin of species. Cambridge, MA: Harvard University Press.

Desmond, A. J. (1989). The politics of evolution: Morphology, medicine, and reform in radical London. Chicago: University of Chicago Press. Desmond, A. J., \& Moore, J. R. (1990). Darwin. London: Michael Joseph. Desmond, A. J., \& Moore, J. R. (2009). Darwin's sacred cause: How a hatred of slavery shaped Darwin's views on human evolution. New York: Houghton Mifflin Harcourt.

Hawkins, M. (1997). Social Darwinism in European and American thought 1860-1945: Nature as model and nature as threat. Cambridge: Cambridge University Press.

Hofstadter, R. (1944). Social Darwinism in American thought, 1860-1915. Philadelphia: University of Pennsylvania Press.

Jones, G. (1980). Social Darwinism and English thought. Sussex: Harvester Press; Atlantic Highlands, NJ: Humanities Press.

Kevles, D. J. (1985). In the name of eugenics: Genetics and the uses of human heredity. Berkeley, CA: University of California Press.

Lightman, B. V. (1987). The origins of agnosticism: Victorian unbelief and the limits of knowledge. Baltimore: Johns Hopkins University Press.

Lightman, B. V. (2007). Victorian popularizers of science: Designing nature for new audiences. Chicago: University of Chicago Press.

Lightman, B. V., \& Fyfe, A. (Eds.). (2007). Science in the marketplace: Nineteenth-century sites and experiences. Chicago: University of Chicago Press.

Paul, D. B. (2009). Darwin, social Darwinism, and eugenics. In J. Hodge, \& G. Radick (Eds.), The Cambridge companion to Darwin (pp. 219-245). Cambridge: Cambridge University Press.

Pearson, K. (1892). The grammar of science. London: Walter Scott.

Secord, J. A. (2003). The extraordinary publication, reception, and secret authorship of Vestiges of the natural history of creation. Cambridge: Cambridge University Press.

Spencer, H. (1891). Essays: Scientific, political and speculative. London: Williams and Norgate.

Uglow, J. (2002). The Lunar men: The friends who made the future 17301810. London: Faber \& Faber.

Weikart, R. (2006). From Darwin to Hitler: Evolutionary ethics, eugenics and racism in Germany. New York: Palgrave Macmillan.

Werth, B. (2011). Banquet at Delmonico's: The Gilded Age and the triumph of evolution in America. Chicago: University of Chicago Press.

Young, R. M. (1985). Darwin's metaphor: Nature's place in Victorian culture. Cambridge: Cambridge University Press.

Janet Browne. Aramont Professor of the History of Science at Harvard University (USA) where she teaches the history of evolutionary theory and the life sciences. Her interests range widely over the natural history sciences. She is chair of the History of Science Department. Previously she taught at the Wellcome Trust Centre for the History of Medicine at University College London and was an associate editor of the early volumes of The correspondence of Charles Darwin in Cambridge (UK). 